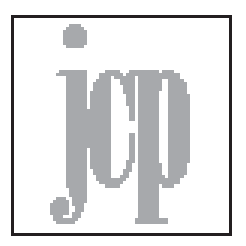

\title{
Violence and Power in Hannah Arendt
}

\author{
Prayer Elmo Raj \\ Assistant Professor, PG \& Research, \\ Department of English, Pachaiyappa's College, Chennai-30, India \\ pelmoraj@gmail.com
}

\begin{abstract}
Hannah Arendt rejects the correlation of politics and violence by disputing that violence is not essentially intrinsic to the political. Violence and power are not identical. Power is instinctively configured by combined and mutual functioning of the multiplicity and differences of citizens. Violence is aphasic, that which aims to detach the citizens by interrupting the civic borders binding them in their deeds. Power is self-binding because it consolidates political agents and public space. However, violence is solely instrumental because it aims to accomplish a defunctive end through force. Power engenders the institution of a "transitory consensus" instigating the opportunity of contention and conflict but violence is catastrophic, incompetent of being creative. Arendt examines how politics has been mutated into violence. In order to consider politics as violence, one has to challenge the complementary correspondence of politics and violence. Countries that press on preventive wars press themselves as good fighting against the evil so as to redeem the future and humanity. To arrive at these goals, countries break international agreements asserting economic and political dominance in an uneven world. While terrorists use violence to destroy their enemies, the use of nuclear and biological weapons by the states could extinguish the entire humanity. States enforce stringent policies against immigrants, refugees and justice movements that coordinate the unemployed, displaced, homeless and the rejected sections of the society. This paper is an attempt to critically examine Arendt's speculations on the interconnection between power and violence and the implications of Arendt's theory in the context of global violence.
\end{abstract}

Keywords: Power, Violence, Arendt, Political, Action 
Throughout the history of political thought, politics is basically "ruling over" and/ or "ruled by." In her analysis of Western political thought, Hannah Arendt finds that political philosophy, ever since Plato, has evaded from understanding the "political" (The Human Condition 222). In contrast to polis, the household (oikos) exhibited the authority of masters over slaves. The political life of Greeks was collaborative and consolidated by a life of free action. Action, in polis, correlates to the condition of human freedom or natality. Public discourse divulged "personal identities" and their "appearance" in the public sphere. Consequently, the organisational expression signified isonomy or equal citizenship. Administered by the rationale of instrumentality, work is "entirely determined by the categories of means and end" (The Human Condition 143). Accordingly, the politics of work entered into a disciplining of human life in conformity with the domain of 'Ideas.' Hence, disciplining became the privilege of a "Philosopher-King" fashioning on a polity of "ruling over." In order to keep the citizens obedient, the Platonic ruler (an individual) employed violence in the political realm similar to the master of a household who exerted violence to "emancipate himself from life's necessity" (Arendt, On Revolution 114).

Arendt advances deeply perceptive observations on "the question of political violence in the political realm" (OnViolence 35) and discusses violence in "political terms.” Quoting Wright Mills she says, "All politics is a struggle for power; the ultimate power is violence" (On Violence 42). Such a point of view is akin to Weber's conception of state as "the rule of men over men based on the means of legitimate, that is allegedly legitimate violence" (On Violence 35). ForWeber, power is authority over individual, group or state. The decisive form of such authority results in violence. Such dominant relationships developed in the pre-political era and had its impact on modern European governments. Arendt challenges one of the fundamental questions of political theorists: "Who rules Whom?" (On Violence 43). Political thinking necessitates an inquisitive discernment. Failure of which signifies "deafness to linguistic meanings" and "a kind of blindness to the realities they correspond to" (OnViolence 43). To consider the rule over humans as legitimate is to legitimise violence. Such a notion of politics of power is historical and inclines on the idea that power is "power over" and make "others act as I choose" (Voltaire quoted in Arendt, On Violence 36). Arendt dismisses political 
power as 'power over.' Politics is not "Who rules Whom?" but an act that binds people together rooted in plurality and equality. Plurality asserts distinctiveness and the ability to articulate a perspective in the public sphere. It allows to "take initiative, to begin [...] [and] to set something in motion" (The Human Condition 177). Political equality anticipates plurality (the Greek isonomy) and legitimacy of being equal "by virtue of citizenship, not by virtue of birth" (The Human Condition 177). Therefore, in public sphere, citizens enter into a dialectic with each other to persuade on issues of public interest. Persuasion entails "debate among political equals, where citizens mutually seek to clarify, test, and purify their opinions" (Bernstein 9). Persuasion, not violence, is the foundation of good polity. When persuasion fails, we move on with reasonable processes of making resolutions. Arendt incorporates her idea of public freedom within these notions. Public freedom is distinct from liberty. Public freedom, though includes liberty, is a decisive political effort that allows individuals to perform together and acknowledge each other as political equals. Power encircles public freedom.

Arendt's political theory and her understanding of power and violence transpire out of a critique of totalitarianism. Totalitarianism parted from the foundations of Western political thought by stringent enforcement of power over its subjects. Total domination, as in the case of totalitarian states, endeavours to nullify unlimited plurality and differences among human beings. Human beings, in totality, are organised into nothing more than individuals with unilinear identity. Terror's total control through violence attempts to destroy power and plurality of human beings. Plurality of human life is invalidated into "bundles of reactions" that are bartered arbitrarily. The desire of totalitarian ideologies "is not the transformation of the outside world or the revolutionizing transmutation of society, but the transformation of human nature itself" (Arendt, The Origins of Totalitarianism 458). Totalitarianism does not emerge out of dictatorship or tyranny but from a systematic procedure that is attempted on dismantling human nature. Violence is foundational to totalitarianism and it attempts to annihilate power by altering human nature. Such an attempt to alter human nature into a redundant category is what Arendt calls "radical evil." The concentration camps became "the laboratories where changes in human nature are tested" (The Origins of Totalitarianism 458). Concentration camps were testing rooms where human nature was assessed through suffering in order to transform human nature. Consequently, totalitarianism impairs the fundamental human disposition, plurality, and fortitude making human beings redundant. Arendt queries if 
totalitarianism has any "essence" of its own or any essential "experience" that could find valid political "expression". To decipher totalitarianism, we need to recognise the function of ideology and terror. Ideologies are the base from which the aggregate of every event is construed. "Ideological thinking orders facts into an absolutely logical procedure which starts from an axiomatically accepted premise, deducing everything else from it; that is, it proceeds with a consistency that exists nowhere in reality" (The Origins of Totalitarianism 471). Terror and violence are not distinctive from totalitarianism because totalitarianism employs the apparatuses of violence. In a totalitarian government, terror is not merely a form of domination but imposition of power in its supreme form to annihilate anyone/anything that stands in its way. Terror, as a result, becomes lawful in a totalitarian domination. Such a condition tyrannises citizens to an extent where fear regulates and naturalises an individual's actions and thoughts. Totalitarian domination and terror motivated by violence employ power in an encompassing manner so as to turn against its enemies and friends without distinction. The ultimate act of terror is accomplished "when the police state begins to devour its own children, when yesterday's executioner becomes today's victim" (The Origins of Totalitarianism 467).

Prior to the explication of the concept of power and violence, Arendt distinguishes the ideas of strength, force, and authority. Strength is inherently individual: "Strength unequivocally designates something in the singular, an individual entity: it is the property inherent in an object or person and belongs to its character, which may prove itself in relation to other things or persons, but is essentially independent of them" (On Violence 44). Force is contingent: "Force, which we often use in daily speech as a synonym for violence, especially if violence serves as a means of coercion, should be reserved, in terminological language, for the "forces of nature" or the "force of circumstances" (la force de choses), that is, to indicate the energy released by physical or social movements" (OnViolence 44-5). Authority is an evasive category. "Its hallmark is unquestioning recognition by those who are asked to obey; neither coercion nor persuasion is needed" (OnViolence 45). In hierarchies (parent-child, teacher-student), authority can be challenged, examined, and derided. These definitions, though subjective and conditional, have wider implications because they "hardly ever correspond to watertight compartments in the real world" (OnViolence 46). 
Arendt's idea of power transpires out of a persistent demand for an alternative against the existing political tradition modelled on pre-politics. Power is an extension of action because the function attributed to power is conservation of public sphere. It is "non-hierarchical and non-instrumental" but envisages a life of togetherness. Non-instrumental character of power is allied with Arendt's understanding of action. Action does not denote an external purpose because it is not connected to work. However, action is aligned with praxis where power is an end in itself. While Arendt does not refute governments pursuing policies to accomplish goals, she warns that power becomes perilous when power structures advance and outlive the goals by manipulating the means to an end. Such a process alters and enables the people to think and act teleologically in an organised and institutionally motivated circumstance. Arendt opposes such political power because power and violence are conflicting "Power and violence are not only distinguishable; they are antithetical. Where power reigns there is persuasion, not violence. And when violence reigns, it destroys power" (Bernstein 6).

Within Arendt's discussion, power defies its individual character by being collective. Power is "inherent in the very existence of political communities" (On Violence 151). Power is engendered when people come together to ascertain, in a public sphere, the greatness of their deeds. It "springs up" when people perform together; it cannot be owned by an individual. Power is conferred upon an individual or a group when it acts in harmony. When power ceases to be collective, power dissipates:

Power corresponds to the human ability not just to act but to act in concert. Power is never the property of an individual; it belongs to a group and remains in existence only so long as the group keeps together. When we say of somebody that he is 'in power' we actually refer to his being empowered by a certain number of people to act in their name. The moment the group, from which the power originated to begin the (potestas in populo, without a people or group there is no power), disappears, 'his power also vanishes.' (OnViolence 44)

No one possesses power but power is present "between" people as they act together. The relational and collective aspect of power contributes to "productivity" of action. Plurality of beings is endowed not in equality or harmony but on the "unitedness" of people, which forms an individual in organisational form, where differences are disbanded to comprehend parity. Power is not indisputable but offers a potential for togetherness that can be accomplished, not embodied. 
Power is parallel, not a configuration where authority is executed top-down. It allows the citizens to perform together, persuade each other, and consider each other as political equals:

Power comes into being only if and when men join themselves together for the purpose of action, and it will disappear when, for whatever reason, they disperse and desert one another. Hence, binding and promising, combining and covenanting are the means by which power is kept in existence; where and when men succeed in keeping intact power which sprang up between them during the course of any particular act or deed, they are already in the process of foundation, of constituting a stable worldly structure to house, as it were, their combined power of action. (On Revolution 175)

Therefore, power is shaped in a communicative model where persuasion among people allows reaching a collective goal. In fact, "Power is what keeps the public realm, the potential space of appearance between acting and speaking men, in existence" (Human Condition 200). Arendt "understands power as the ability to agree upon a common course of action in unconstrained communication" (Habermas 3). Power is realised as a sphere where word and action assimilate together to forbid empty words and actions from becoming atrocious. It prevents words from shrouding its intentions by divulging realities and actions that do not obliterate but engender new realities and ascertain communicative action. Power is not an organised assertion of will against others but a development of a "common will in a communication directed to reaching agreement" (Habermas 4).

Power is at the core of every government and is an "end-in-itself." Power as "power over" annihilates distinctiveness and smothers freedom and efficacy. It is fundamentally associated with "being-with" which is innately more detrimental than implemental violence and compliance of the governed that is organised for collective objectives. The willingness to collectively support the political headship and governance contributes to political life. However, employment of "force" denotes the disposal of sources and means of persuasion by political headship to secure decisions to reach collective goals. Unlike Weber, Arendt disassociates power from being a teleological category. Power functions to uphold the praxis and strengthens political organisations to protect the communicative aspect of public life. Therefore, power preserves freedom and acts in reticence to forces that terrorise liberty. When people sustain their support, institutions of a country become powerful because all "political institutions are manifestations and materializations of power" (OnViolence 41). The support of people is consent. 
However, "they petrify and decay as soon as the living power of the people ceases to uphold them" (OnViolence 41). When power is lost, political communities become impotent and cease to communicate. Unlike violence, which finds manifestation in the instruments, power cannot be conserved because power is people-centred and exists only in actualisation. Power cannot be equated with violence because the nature of power is contradictory to the nature of violence. The nature of violence is unpredictable. To rule over a group of people to accomplish one's will is not power. However, power brings together people in consent. Power is contingent on relationship. Therefore, when people unite for an accepted course of action, a powerful community is formed. Arendt considers power that arises out of a ruler or group as impotence. It is only anxiety and despondency on part of the government about losing power which triggers the implement of violence. Violence can annihilate power by dividing and averting people from acting together. Simultaneously, power can also be enhanced by people who actively support the government.

Arendt's On Violence is a reflection on contemporary events and literature on violence by Sorel, Fanon, and Sartre. Arendt censures Sartre for his negligent veneration of violence. In the "Preface" to The Wretched, Sartre writes, "To shoot down a European is to kill two birds with one stone [...], there remain a dead man and free man [...]This is a sentence Marx could never have written" (quoted in On Violence 13). Sartre seems to have misread Marxism and existentialism (Bernstein 5) when he says "irrepressible violence [...] is man creating himself," and that it is through "mad fury" that "the wretched of the earth" can "become men" (OnViolence 12). Fanon really advocates that an explicit notion of violence is debatable, because he was conscious that violence might lead to the defeat of any movement that challenges oppressive power. Thus, violence remains ambiguous within the idea of the "political" and the lineage that fundamentally distinguish itself with indistinctness.

Violence is a blatant display of power. It emerges when power is disoriented and the relationship between a ruler and citizens is disturbed.Violence can obliterate power but "it can never become a substitute" for power because "power comes into being only if and when men join themselves together for the purpose of action" (Arendt, "Personal Responsibility" 37). When power fails to preserve the citizens as equals, authority displaces harmony and persuasive speech in a public 
sphere. The menace of violence is, the means overwhelms the end. As a result, "If goals are not achieved rapidly, the result will be not merely defeat but the introduction of the practice of violence into the whole body politic" (OnViolence 80 ). The interconnectedness of violence and power is impendence to solidarity and political existence. Arendt overlooks the impact and distinguishing nature of political violence which acts-in-concert with power centres. When a gunman controls a crowd, it indicates the network of relations that position technology in the hands of a gunman rather than annihilating power of technology. That violence erupts out of infecundity and violence cannot engender power as contestable. For Arendt, "non-violent" power is superfluous because power and violence are antithetical.Violence can exterminate power by dismantling faith between actors. When government fears that their "power over" citizens is abating or when citizens renounce political freedom, violence arises. Therefore, violence, for Arendt, is also an instance of "frustration" or breach of commitment. However, this claim cannot be generalised because there are historical instances where fading powers or empires have relinquished to demands in non-violent ways. The British Raj could not continue to pursue its violent ways when the freedom struggle in India took a non-violent turn and had to cede (see also Eichmann in Jerusalem 288). This also offers a prime illustration of how violence can be countered through non-violent means. Nevertheless, Arendt punctuates the need to counter and defend violence keeping in mind the magnitude and dimensions of power and violence. For Arendt, "risky as a deployment of violence is, there are contexts in which people acting in concert politically must do so, most importantly because political power alone is never stronger than violence" (OnViolence 157).

Violence is distinguished by its instrumental character. Phenomenologically, it is close to strength, since the implements of violence like other tools are designed and used for the purpose of multiplying natural strength until, in the last stage of their development, they can substitute for it. (On Violence 46)

Methodological progress of the implements of violence cannot logically complement the annihilative capability and justification of the use of arms because violence is aphonic and instrumental in action depending on implements lacking any relation to the political. As a result, violence and power become oppositional, "where the one rules absolutely, the other is absent" (On Violence 155). Violence as a constitutive implementation of instruments performs an intentional form of domination. Justifying the production of the implements of violence cannot 
be justified because it is temporal in its outlook. Moreover, the implements of violence cannot be replaced by inter-subjectivities. Involvement of machinery in violence to augment its strength is antithetical to power. As a consequence, power can neither involve political violence nor obedience: "Violence can always destroy power: out of the barrel of a gun grows the most effective command, resulting in the most instant and perfect obedience. What never can grow out of it is power" (OnViolence 53). The nature of violence is instrumental and by "all means it always stands in need of guidance and justification through the end it pursues" (Arendt, "Communicative Power" 68). However, the fact that violence is not ascribable with implements alone allows Ardent to observe the discontinuous and contravening aspects of power. In order to challenge the rationale of instrumental cause of violence as a transformative agent of the political, Arendt recommends that the political "comes to the fore where people are with others and neither for nor against them - that is, in sheer human togetherness" (The Human Condition 180) in ethico-political sphere.

Violence silences people. Therefore, in political life, silence makes violence a "marginal phenomenon" because power is persuasive and human beings are political beings equipped with speech. Violence is incompetent of speech and hence "speech is helpless when confronted with violence" (On Revolution 18-19). In contrast to the speechless nature of violence is the instrumental nature of violence. For this reason, the mute nature of violence can be fatal. "But power requires speech and articulation" (Bernstein 14). To speak about violence, one has to disassociate oneself from violence and from the "lived experience of violence" (Bernstein 12). The coercive nature of violence is oppositional to public speech. To be part of the lived experience of violence defies oneself from expressing publically and persuasively the pain and trauma caused by violence. It is not the organisation or regulations that engender violence but violence by itself wields a powerful silencing mechanism where language becomes secondary. Violence nudges off the differentiation between speakable and unspeakable to assert the un/speakable. Such assertion destructs the boundaries of speech and persuasion making it impossible for self-expression. Moreover,

[G]iven the play of normative prohibitions in mental life, it is never clear at the outset, if ever, what about the boundaries in question are the effect of violence and what is an effect of normative prohibitions. In addition, the boundaries are permeable. They can and do change over time. (On Violence 15) 
We cannot predict the dynamics of violence because it is often manipulated to achieve ends that are distinct from political life. Violence is not a natural act. Arendt observes violence as akin to human emotion and a medium to vent human emotions. The act of violence, however, is removed from the "natural" human emotion because it contradicts ethical justifications even if it is well-intentioned (See Gail 130). When power embraces violence, there is hardly any outcome but destruction. It is when there is a loss or deficit of power, the (politically) powerful take refuge in violence. However, in real political scenario, we hardly ever find power and violence in "extreme form" or "pure states." Violence differs from power by having an external purpose to accomplish and it needs no justification.

Arendt does not systematically discuss the various forms, influence, dynamics and impact of violence. How violence works intrinsically with power is unclear in Arendt's exposition. How and why violence is justified in many cases by those in power finds no answer in Arendt. Power cannot be accumulated at a sole point because it emerges not as a foundation but by actualisation. What is actualised in and through power is human freedom that willingly acts together as the capability of citizens in political life. Accordingly, power is independent of materiality. However, in contemporary socio-political life, freedom is influenced by the powerful/government. Freedom is politically limited and socially guided in today's public sphere. When an individual or group fails to abide by these restricted freedoms granted by rulers, law, and the powerful, violence is exerted on them. Psychological fear is enforced on those who exercise free speech in public sphere. Fear of being named and isolated in society is also the effect of the nexus between power and violence. The ability of a group that is organised and sovereign to be nonviolent and revolutionary emerges through the coexistence of people and not the material factor. Today, the limits of power are rooted in the formation and existence of power groups. The limits of power are realised by an efficient plurality which disintegrates power centres and fades away when dominated. When power is accumulated in a power centre or powerful personality, power is unaided. Such power disbands plurality into homogeneity where people are ruled over. Instead of protecting the plurality of identities and voices in public sphere, governments divide and rule. Plurality confines power to its strength and indivisibility. Plurality as the foundational condition of political life involves intersubjectivity. Intersubjectivity engages the validity of the political deriving 
not on individual convictions but on the "process of exchange of opinion against opinion" (On Revolution 227). Violence evolved out of totalitarianism is a rupture in the logic of intersubjectivity. As the ancients forced inevitability into freedom by imposing on others to accept the burden of life, 20th century supplanted humans with controlling and manipulative technologies. At the heart of Arendt's attempt to distinguish violence from power are the concurrences requisite for freedom and the advent of modern society that challenges the experience of the political. Offering us a critical cue for thinking about power in the current political life, Arendt emphasises "when human beings act together, the way in which it can grow, the way in which it can become revolutionary" (Bernstein 12). How far can we express and act together in public sphere when freedom is contentious. Freedom to express and act together in public sphere is the space for true expressions of power. However, to act together in the name of revolution cannot justify violence because violence represents "its political limitation; if, instead, it arrives at a glorification or justification of violence as such, it is no longer political but antipolitical" (On Violence 19). Therefore, violence cannot actualise revolution that leads to liberation. It is only revolution along with public freedom that can achieve liberation.

Arendt challenges the Platonic foundation of Western political thought. That Arendt does not propose a significant alternative to the instrumental nature of violence is crucial. Arendt, as she exposes the obscurity of dualisms, realises that the nexus between power and violence is not confined to the "social" and "nonpolitical" but explicitly lays bare the complexity that interconnects freedom and power to the "political." The prospect of the "political" in the context of power and violence is deeply perceptive. Violence and counter-violence are possibilities, not possible inevitabilities or imperatives. Today violence pretends to be counter-violence by exerting violence over the other. The fight against terror is named as a fight for justice and protection. Immigrants entering a country are viewed as a threat to the political and social stability of a nation state. Building a homogeneous nation state and promoting particular cultural values through coercion is justified. Violence is not a dispassionate reality existing universally as an impetus for counter-violence. Exploitation and reciprocity of power account for the destruction of human beings. Counter-violence modifies itself as a process of reinstatement against aggravation to counter violence. Terrorism is considered not as same as violence. Arendt deems that it is the government which is in total control even when violence in the name of terrorism is spread. The efficacy of 
terror can be acknowledged and recognised only through a "degree of social atomization." Therefore, the 'political' anticipates any controlled opposition that disperses violence in order to terrorise.

Habermas is right when he argues that Arendt "does not test her hypothesis against examples of the decline of great empires" (9). Arendt's conception of power and violence is challenged by the issues of power and violence that ascended after the globalisation. Arendt's historical investigation is limited to the instances of struggle for political freedom under totalitarian regimes and the revolutionary enterprises that battled for freedom. Current political scenario exhibits subtle display of "power over." Democratic political orders segregate its citizens, sever public opinions and execute violence destroying communicative structures. Dominant political orders execute power over the economically backward and socially segregated through tactical and indirect employment of power and violence. Most of the ground realities such as imperialism, neo-imperialism, immigration, poverty, economic disparity and state sponsored violence against religious, sexual, and ethnic minorities are treated as ideological. Violence based on discrimination is not involuntary but intentional and pondered. The struggle against discriminatory violence, therefore, is a struggle against prejudice and an obvious ideological system that is supported by power. Infliction of violence on the basis of discrimination is ideological more than instrumental. Such a manifestation of violence is inherently detrimental and hard to confront by Arendt's idea of power as "being with."

While dealing with the horrors of 20th century, Arendt acknowledges the restricted role of implemental violence. The "realm of necessity" assuages biological/natural wants in opposition to collaborative politics of the equals in the public sphere. The pre-modern society satisfied their need by enslaving others in the private sphere but in the modern society, technology supplanted slavery in satisfying natural wants. "Because all human beings are subject to necessity, they are entitled to violence toward others; violence is the pre-political act of liberating oneself from the necessity of life for the freedom of the world" (The Human Condition 31). Unlike slavery, which is a direct domination, technology, with its regulatory framework, displays "violation and violence" rendered in all "fabrication" (The Human Condition 139). 
Political power declines in the context of centralisation of bureaucracy. Centralisation, though efficacious in its performance, reinforces the capacity to control by exhausting people's ability for political action. When government employs technoscience, it deteriorates political power because decisions are made by experts rather than the government. Decisions are made 'on behalf of' the government by experts of technoscience. Such circumstances also indicate decline of power because power becomes a fragmented network. Therefore, enforcement of power through coercion or violence exerted by government symbolises waning of power. To counter the peril of violence is to stop the decline of political power. Arendt acknowledges the role of social movements in 1960's in countering the decline of political power. When Arendt argues violence cannot be legitimate but only "justified" for reasons of self-defence and liberation from oppression, the contradiction remains because she catalogues politics alongside friendship. In this regard, instead of establishing the political, power permeates boundaries without restraints because of non-authoritative "being with". Moreover, whether violence can be justified as a political realisation or as a political reformative involving the citizens remains dubious because as John McGowan implies, the "act of justification" is "performative whose success depends on convincing one's interlocutors that violence is necessary" (288). Violence and power do not bond together to achieve any privileged state of affairs in politics but they do have common root. When one chooses to be in pristine form, the other does not exist. Violence cannot be deciphered through power. In order to understand violence, one has to trace its nature, composition and dynamics. Having argued that violence is ingrained in human emotions such as anger, Arendt does not find any rationality behind the use of violence at any circumstance. To confront evil through violence does not justify violence or aid whoever experiences suffering. Evil destroys social sphere as much as violence does. We cannot transcend evil and violence through power because both are radically destructive in nature. At certain moments of crisis, Arendt considers violence as legitimate and rational. In the case of self-defence and liberation from oppression, violence is justified. Quoting William O' Brien, she notes, "Sometimes 'violence is the only way of ensuring a hearing for moderation'” (On Violence 79). However, Arendt does not term such instances as political because they are removed from the dynamics and significance of political life. Power could be legitimate when it strives to achieve its aim. Here, power engenders affiliation, "acting-in-concert" with the political. Conversely, violence as engaged within the network of relationships is endangered because violence is politically marginal when a human being is 
endowed with collaborative/collective politics in the public sphere.

Arendt justifies violence for political purposes. She backed the formation of a Jewish army to counter Hitler. She believes that one can defend oneself "as the person you are attacked as" (The Jewish Writings 137). To assault an individual is to assault his/her identity and essence of existence. Therefore, "[i]f one is attacked as a Jew, one must defend oneself as a Jew. Not as a German, not as a world-citizen, not as an upholder of the Rights of Man or whatever" (Essays in Understanding 10). It becomes a stipulation on part of the Jewish people to form an army to fight for their freedom and assert their right to live. "Only the people themselves, young and old, poor and rich, men and women, can reshape public opinion, which today is against us. For only the people themselves are strong enough for a true alliance" (The Jewish Writings 138-9 Arendt's Italics). Arendt's justification of violence, in this case, is closer to reality. It arises out of pushing Jews towards a state of dystopia. Instead of being a utopian to argue against the formation of an army, Arendt appropriates a real-world situation where power is countered with violence. In a real world dystopic situation, power cannot succeed without violence. Hence, it is the "privileged moments" that allow us to discern the politics of violence in reality (See Bernstein 25). Arendt's support for a Jewish Army is a call to reinaugurate the Jewish identity and solidarity in order to politically re-organise / self-organise themselves. An army becomes the crucible and catalyst for Jewish freedom where they could create a public space. However, unlike Arendt's dualist stance, the above instance only augments the idea that violence and power are concerted and "mutually reinforcing." To conclude, Arendt's inclination towards the political as an expression and act together in concert could derive legitimacy when it relates to a particular end. Violence, however, loses its feasibility when its means is justified by its end.

\section{Works Cited}

Arendt, Hannah. "Communicative Power." Power. Ed Steven Lukes. Washington Square, New York: New York UP, 1986. 59-74. Print.

---. Eichmann in Jerusalem. New York: Penguin, 1977. Print.

---. On Revolution. New York: Penguin Books, 1977. Print.

---. OnViolence. Orlando: Harcourt Inc., 1969. Print.

---. The Human Condition. Chicago: U of Chicago P, 1958. Print.

---. The JewishWritings. New York: Schocken Books, 2007. Print.

---. The Origins of Totalitarianism. Orlando: Harcourt Inc., 1976. Print. 
Bernstein, Richard J. “Hannah Arendt's Reflections on Violence and Power.” Iris: European Journal of Philosophy and Public Debate 3.5 (Apr 2011): 3-30. Print.

Canovan, Margaret. Hannah Arendt: A Reinterpretation of Her Political Thought. Cambridge: Cambridge UP, 1992. Print.

Frazer, Elizabeth. "Power and Violence."Hannah Arendt: Key Concepts. Ed. Patrick Hayden. New York: Routledge, 2014. Print.

Gines, Kathryn T. “Arendt's Violence/Power Distinction and Sartre's Violence/ Counter-Violence Distinction: The Phenomenology of Violence in Colonial and Post-Colonial Context." Phenomenologies of Violence. Ed. Michael Staudigl. Leiden: Brill, 2014. Print.

Gines, Kathryn T. Hannah Arendt and the Negro Question.Bloomington and Indianapolis: Indiana UP, 2014. Print.

Habermas, Jürgen. “Hannah Arendt's Communications Concept of Power.” Social Research 44.1 (Spring 1977): 3-24. Print.

King, Richard H. Arendt and America. Chicago: U of Chicago P, 2015. Print. Lakitsch, Maximilian. "Reconsidering Political Power in Times of Social Unrest and Revolution: An Introduction.” Political Power Reconsidered: State Power and Civic Activism between Legitimacy andViolence, Peace Report 2013.Zurich and Berlin: LIT, 2014. 9-16. Print.

Lefort, Claude. Democracy and Political Theory.Trans. David Macey. Minneapolis: U of Minnesota P, 1988. Print.

McGowan, John. "Must Politics be Violent? Arendt's Utopian Vision.” Hannah Arendt and the Meaning of Politics. Eds. Craig Calhoun and John McGown. Minneapolis: U of Minnesota P, 1997. 263-296. Print.

On, Bat-Ami Bar. The Subject of Violence:Arendtean Exercises in Understanding.Lanham: Rowman \& Littlefield Publishers, INC., 2002. Print.

Peeters, Remi. “Against Violence, But Not at Any Price: Hannah Arendt's Concept of Power." Ethical Perspectives: Journal of the European Ethics Network 15.2 (2008): 169-192.

Presbey, Gail M. "Hannah Arendt on Power."Philosophical Perspectives on Power and Domination:Theories and Practices. Eds. Laura Duhan Kaplan \& Laurence F. Bove. Armsterdam \& Atlanta, GA: Rodopi, 1997. 29-40. Print.

Toit, André du. "Discourse on Political Violence." Political Violence and the Struggle in South Africa. Ed. N.Chabani Manganyi and André du Toit. New York: Palgrave Macmillan, 1990. Print.

Weiss, Gail. Refiguring the Ordinary.Bloomington and Indianapolis: Indiana UP, 2008. Print. 